九州大学学術情報リポジトリ

Kyushu University Institutional Repository

\title{
Transfection and Transformation Systems for Pock-Forming and Thiostrepton-Producing Streptomyces azureus
}

Ogata, Seiya

Laboratory of Applied Microbiology, Faculty of Agriculture, Kyushu University

Koyama-Miyoshi, Yuko

Laboratory of Applied Microbiology, Faculty of Agriculture, Kyushu University

Hayashida, Shinsaku

Laboratory of Applied Microbiology, Faculty of Agriculture, Kyushu University

https://doi.org/10.5109/23804

出版情報：九州大学大学院農学研究院紀要. 29 (4)，pp.179-188，1985-06. Kyushu University バージョン：

権利関係 : 


\title{
Transfection and Transformation Systems for Pock-Forming and Thiostrepton-Producing Streptomyces azureus
}

\author{
Seiya Ogata, Yuko Koyama-Miyoshi and Shinsaku Hayashida \\ Laboratory of Applied Microbiology, Faculty of Agriculture, \\ Kyushu University 46-02, Fukuoka 812 \\ (Received January 31, 1985)
}

\begin{abstract}
To establish a procedure for high frequency transfection and transformation of Streptomyces azureus, at first, the condition for the protoplast formation and regeneration of this strain were studied. The effective formation and regeneration of protoplasts of S.azureus were obtained by using mycelia grown in the presence of $0.4 \%$ glycine. The effective transfection of S. azureus protoplasts with temperate phage SAt 1 DNA was obtained at $20 \%$ (W/V) PEG 2000. The frequency of transfection under the optimal condition was about 1 per $5 \times 10^{6}$ DNA molecule (equal to $5 \times 10^{3}$ transfectants per $\mu$ g DNA) and 1 per $5.3 \times 10^{3}$ regenerated protoplasts. The DNA transfection of a virulent phage SAvl was also succeeded in the protoplasts of S. azureus. The transformation of pock-cured strain AF-6 of S.azureus with pock-inducing plasmid DNA occurred under the same condition as transfection of phage SAtl DNA.
\end{abstract}

\section{INTRODUCTION}

This study was carried out with the aim to establish the transfection and transformation systems of an antibiotic (thiostrepton) -producing Streptomyces azureus.

Streptomyces species produce many industrally important antibiotics and physiologically active substances. The protoplasts of these microorganisms are useful in genetic studies and molecular breedings using protoplast transformation or transfection and fusion techniques. The basic conditions for handling Streptomyces protoplasts were deveroped largely by Okanishi et al. (1974) and adapted with minor modifications by many investigators (Shiraha. ma et al., 1981; Pigac et al., 1982; Ogawa et al., 1983). Therefore, as first step of this work, we demonstrated the protoplast formation and regeneration in S. azureus. It forms unique pocks with the production of phage tail-like particles in the lawn of plate cultures, as reported in previous paper (Ogata et al., 1981). A plasmid, which is associated with pock formation, was isolated from this strain (Ogata et al., 1983). The pock formation of this strain has common phenotypic features with "pocks" like Streptomyces coelicolor and others (Bibb et al., 1978; Thompson et al., 1983), but there are some distinct differencies among them, as also described elsewhere (Ogata et al., 1981). The protoplast formation and regeneration procedures will help genetic studies of pockforming S. azureus involving fusion, transformation and transfection. In this 
paper, the condition for the protoplast formation and regeneration of this strain are clearly described.

Recently some efficient transformation (Bibb et al., 1978) and transfection (Krügel et al., 1980 Suarez et al., 1980, Isogai et al., 1980, Toyama et al., 1983) systems for Genus Streptomyces were established using their protoplasts. So, it is anticipated that the bacteriophages will be used as cloning vectors in genetic manipulation for Genus Streptomyces. But their abilities as vectors depend on the characteristics of phage and phage-host systems. We isolated a temperate phage SAtl infectious to S. azureus (Ogata et al., 1985)from soil sample. As the second stage of this work, condition for the efficient transfection system using the protoplasts from S. azureus and SAtl DNA is described in this paper. Furthermore, the transformation system using pock-inducing plasmid DNA is investigated as the last step of this work.

\section{MATERIALS AND METHOD}

\section{Bacterial and phage strains}

Streptomyces azureus ATCC 14921 and its phage SAtl (temperate) were used throughout this work. Streptomyces endus KCC S-0213, S. coerulescens KCC S-0360, S. lavendulae KCC S-0263, S. rimosus KCC S-0073, S. griseus NRRL B-2926, S. Zividans KCC S-0783, were also used. These bacterial strains were supplied by Dr. A. Seino (KCC Culture Collection of Actinomycetes). Also a pock-cured mutant AF-6 (Ogata et al., 1983) of S.azureus and a virulent phage SAvl (isolated from soil) were used in the transformation experiment and transfection experiment, respectively.

\section{Media, reagents and enzymes}

Bennett medium and agar (glucose, $1.0 \%$, meat extract, $0.1 \%$; yeast extract, $0.1 \%$; NZ-amine type A, $0.2 \%$; agar, $1.5 \%$ (hard) or $0.7 \%$ (soft) ; pH 7.2), Rye flake agar (rye flakes, $1.0 \%$; glucose, $0.2 \%$; yeast extract, $0.1 \% ; \mathrm{CaCO}_{3}$, $0.3 \%$; agar, $1.5 \% ; \mathrm{pH} 7.2$ ) and MG-1 medium (glucose, $1.0 \%$, NZ-amine type A, $0.4 \%$; yeast extract, $0.2 \%$; beef extract, $0.2 \%$; glycine, $0.4 \% ; \mathrm{pH}$ 7.2) were used for the growth of organisms and phages. PWP buffer was prepared as described by Shirahama et al. (1981) and modified R 3 medium (sucrose, $0.4 \mathrm{M}$; glucose, $1.0 \%$; NZ-amine type A, $0.4 \%$; yeast extract, $0.4 \%$; $\mathrm{KCl}, 0.05 \% ; \mathrm{MgCl}_{2} \cdot 6 \mathrm{H}_{2} \mathrm{O}, \quad 40 \mathrm{mM} ; \mathrm{CaCl}_{2} \cdot 2 \mathrm{H}_{2} \mathrm{O}, \quad 15 \mathrm{mM} ; \mathrm{K}_{2} \mathrm{HPO}_{4}, \quad 0.002 \%$ : Tris- $\mathrm{HCl}, 0.025 \mathrm{M}$; agar, $1.8 \%$ (hard), low melting point agar, $0.7 \% ; \mathrm{pH} 7.2$ ) was used for the regeneration of protoplasts.

PEG 2000 was purchased from Nakarai Chemicals Ltd. Egg white lysozyme was from Seikagaku Kogyo Co. Ltd.

\section{frequency}

Preparation and regeneration of protoplasts, and estimation of regeneration

Spores (about $10^{8}$ colony forming units (cfu)) were inoculated into $50 \mathrm{ml}$ of Bennett medium and grown for $24 \mathrm{hr}$ at $28^{\circ} \mathrm{C}$ on a rotaly shaker $(250 \mathrm{rpm})$. This cultivated broth was transferred (5\% v/v) to MG-1 medium, and cultivation was further carried out under the same conditions as above for $24 \mathrm{hr}$. 
Then the mycelia were harvested by centrifugation $(5,000 \times g)$, suspended in PWP buffer supplemented with lysozyme $(1 \mathrm{mg} / \mathrm{ml})$, and incubated at $30^{\circ} \mathrm{C}$, for 30-60 min with gentle shaking. After that the protoplast suspension was centrifuged at $200 \times g$ for $5 \mathrm{~min}$ to remove the intact mycelia and cell debris, and the protoplasts in the supernatant were pelleted by centrifugation at 500 $\mathrm{xg}$ for $10 \mathrm{~min}$. The protoplasts precipitated were gently suspended in $1 \mathrm{ml}$ of PWP medium. The number of protoplasts converted was estimated by microscopic counts of 10 random haemocytometer fields. The percentage of regeneration was estimated by comparing the colony forming units (cfu) on modified R 3 agar plates with the number of protoplasts present. The protoplast suspension was also diluted with water and plated on the same agar except for the $\mathrm{Mg}^{2+}, \mathrm{Ca}^{2+}$ and sucrose to determine the number of the osmotically resistant cells (nonprotoplast cells) in the protoplast suspension.

\section{Phase contrast microscopy}

Samples were observed with a phase contrast microscope (Nippon Kogaku Kogyo Ltd.) and photographs were taken using Fuji minicopy film.

\section{Electron microscopy}

Electron microscopical specimens were prepared by the method of Kellenberger (Higashi et al., 1973) but $0.3 \mathrm{M}$ sucrose was added to osmium fixative to prevent the bursting of protoplasts. Samples were observed with JEM-100 B electron microscope (Japan Electron Optical Laboratory Ltd).

\section{Preparation of phage particles and phage DNA}

Preparation of phage particles and phage DNA were carried out as described in our previous paper (Ogata et al., 1985).

\section{Transfection}

A $50 \mu$ of $30 \%(\mathrm{w} / \mathrm{v})$ PEG2000 in medium PWP was added. The mixture was incubated at $32^{\circ} \mathrm{C}$ for $3 \mathrm{~min}$. After being diluted with $5 \mathrm{ml}$ of medium PWP, the protoplasts were centrifuged $(1000 \mathrm{x} \mathrm{g}$, for $10 \mathrm{~min})$ to remove PEG 2000. The pellet of protoplasts was suspended in $1 \mathrm{ml}$ of medium PWP.

\section{Transfection assay}

(1) Infective center assay after phage DNA transfection.

A portion of the transfection mixture was diluted appropriately with PWP and plated with spore suspension of S. azureus (abut $10^{7} \mathrm{cfu} / \mathrm{plate}$ ) on the modified R3 agar according to double layer method. The plaques occurred were counted after $40 \mathrm{hr}$-incubation at $28^{\circ} \mathrm{C}$. This number reveals the number of transfectants.

(2) Free phage assay.

A portion of the transfection mixture was transferred to the modified $\mathrm{R} 3$ liquid medium in L-tube and incubated at $28^{\circ} \mathrm{C}$ with gentle shaking. After appropriate intervals during incubation, the aliquots were diluted with $0.05 \mathrm{M}$ Tris-hydrochloride buffer (pH7.2) containing $0.1 \mathrm{M} \mathrm{Mg}^{2+}$ and plated with spore suspension of $S$. azureus (about $10^{7} \mathrm{cfu} / \mathrm{plate}$ ) on the Bennett medium 
according to the double layer method. The plaques were counted after $48 \mathrm{hr}$ incubation at $28^{\circ} \mathrm{C}$.

\section{Preparation of plasmid DNA}

For the preparation of plasmidpSA 1 DNA of S. azureus, the mycelia from the cellophane-coated plate cultures were gathered, and then lysed following the methods of Chater et al. (1982) $: 5 \mathrm{mg} / \mathrm{ml}$ of lysozyme was used instead of $2 \mathrm{mg} / \mathrm{ml}$. The cleared lysate was centrifuged to obtain a clear nonviscous supernatant, and then used for the precipitation and isolation of plasmid DNA by CsCl-EtBr density gradient centrifugation (Maniatis et al., 1982).

\section{Transformation and its assay}

The pock-transforming activity of purified pSA 1 DNA was examined following the methods of protoplast transfection described above; $1 \mu \mathrm{g} / \mathrm{ml}$ of extracted pSA 1 DNA was transferred into $2 \times 10^{8}$ protoplasts of pock-cured strain AF-6 per ml. The transformants were detected by the appearance of pocks in the lawn of strain AF-6 used as an indicator when the regenerated colonies were plated together with strain AF-6.

\section{RESULT AND DISCUSSION}

\section{Formation and regeneration of protoplasts}

Okanishi et al. (1974) showed that the formation of Streptomyces' protoplasts can be accomplished by using mycelia grown in the presence of subinhibitory concentration of glycine. They determined a suitable glycine concentration for the protoplast formation of certain Streptomyces species, but S. azureus could not grow enough in this condition. So, we examined the growth of mycelia and the formation and regeneration of protoplasts. Growth of the cells was decreased in accordance with increasing of the concentration of glycine (Table 1). In the presence of $0.2 \%$ or more glycine the protoplasts were formed, but in the presence of $1.0 \%$ or more glycine, the large clump of mycelia formed during precultivation, therefore, the rate of formation and regeneration of protoplasts decreased, as shown in Table 1. The optimal forma-

Table 1. Effect of glycine (\%) in MG-1 medium on growth of cells and formation and regeneration of protoplasts

\begin{tabular}{|c|c|c|c|}
\hline $\begin{array}{l}\text { Concentration of glycine } \\
(\%) \text { in MG-1 medium }\end{array}$ & $\begin{array}{c}\text { Relative growth } \\
(\%)\end{array}$ & $\begin{array}{c}\text { Protoplast formation } \\
(\mathrm{No} / \mathrm{ml})\end{array}$ & $\begin{array}{c}\text { Protoplast regenera- } \\
\text { tion }(\%)\end{array}$ \\
\hline $\begin{array}{l}0.2 \\
0.4 \\
0.6 \\
0.8\end{array}$ & $\begin{array}{r}102 \\
92 \\
85 \\
69\end{array}$ & $\begin{array}{r}<10^{4} \\
7 \times 10^{6} \\
2 \times 10^{8} \\
2 \times 10^{8} \times 10^{8}\end{array}$ & $\begin{array}{l}\text { N D } \\
45 \\
45 \\
23 \\
12\end{array}$ \\
\hline 1: 0 & 59 & ND & ND \\
\hline
\end{tabular}



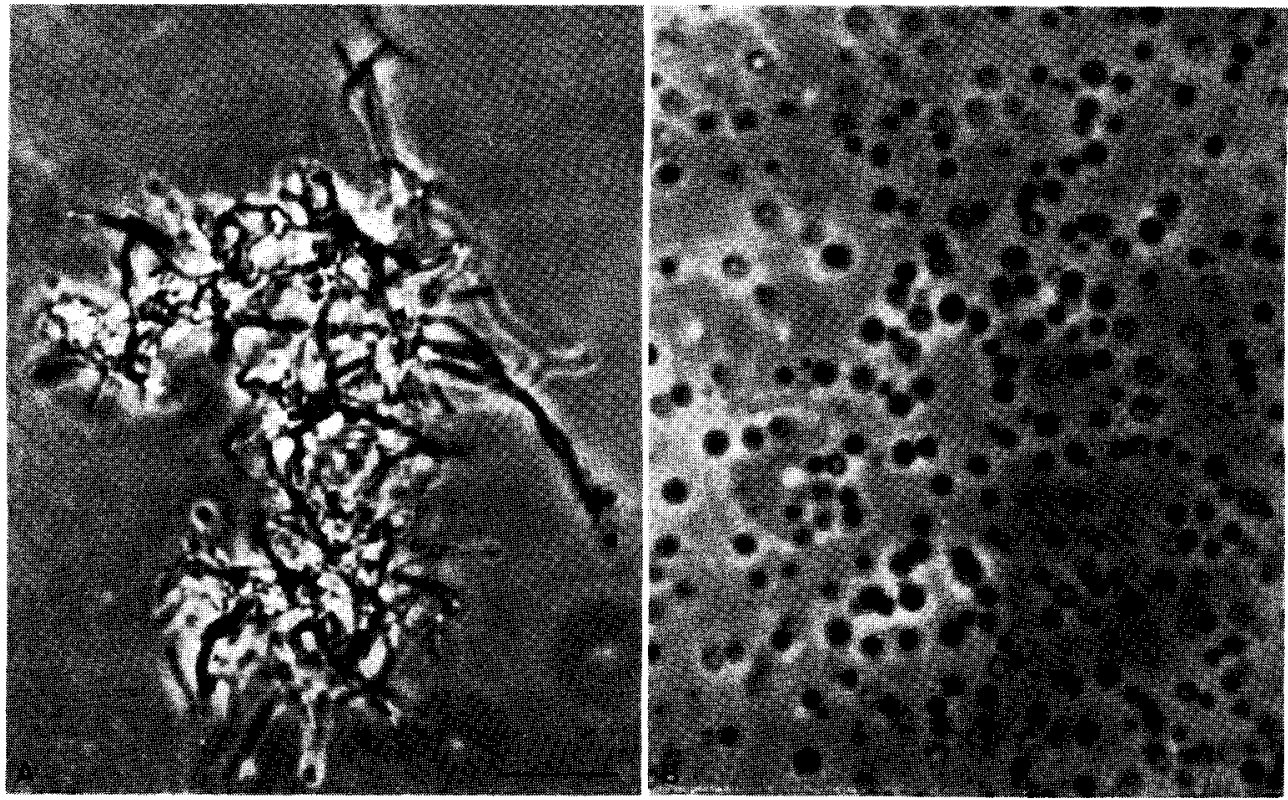

Fig. 1. Morphological changes in Streptomyces azureus during its protoplast formation observed with a phase contrast microscope.

Photographs were taken before (A) and after 60 min incubation (B). Scale indicates $10 \mu \mathrm{m}$.

tion and regeneration of protoplast of S. azureus were obtained by using mycelia grown in the MG-1 medium containing $0.4 \%$ glycine.

Figure 1 shows the morphological changes of $\mathrm{S}$. azureus, under a phase contrast microscope. When the changes from mycelia to spherical cells (protoplasts) occurred, unicells were separated from the clump of mycelia. Almost all mycelia were converted to protoplasts in 60 min (Fig. 1-B). An electron microscope shows all cells became protoplasts with no cell wall (Fig. 2).

\section{Effect of PEG 2000 concentration on the transfection frequency}

Figure 3 shows the effect of the concentration of PEG2000 on the frequency of protoplast-transfection of S. azureus with SAt 1 DNA. The number of transfectants depended on PEG concentration. Optimal transfection was obtained with $20 \%(\mathrm{w} / \mathrm{v})$ PEGZOOO. No transfection was detected with less than 10 \% PEGZOOO. When more than 20 \% PEG2000 was used, the frequency decreased. This decrease may be due to the aggregation or fusion of the protoplasts.

\section{Effect of DNA concentration on the transfection frequency}

The effect of SAt 1 DNA concentration on the frequency of protoplasttransfection of S. azureus is shown in Fig. 4. The frequency of transfection 


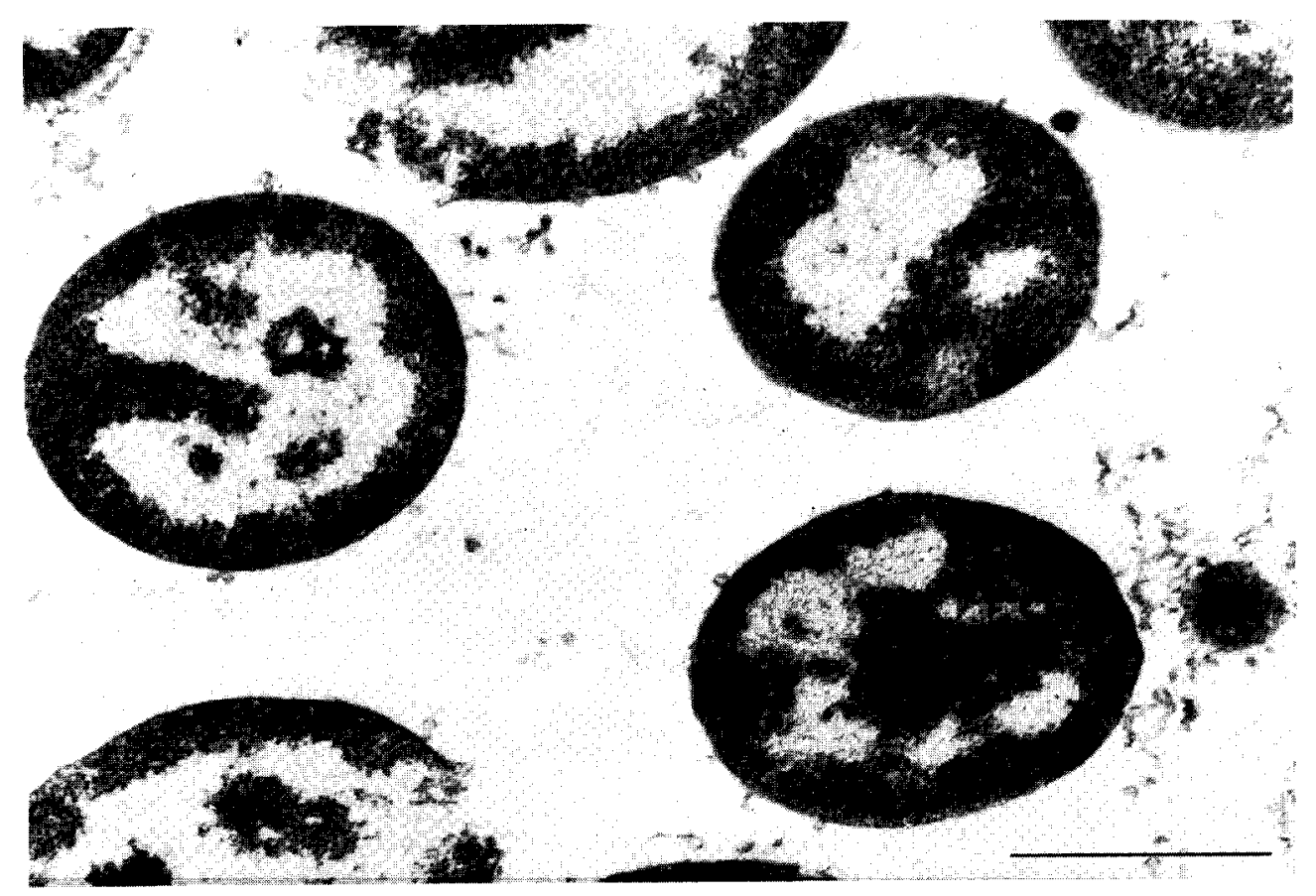

Fig. 2. Electron microphotograph of ultrathin section of Streptomycesazureus protoplasts.

Scale indicates $1 \mu \mathrm{m}$.

increased in proportion to the amount of DNA added up to $300 \mathrm{ng}$ DNA (about $7.7 \times 10^{9}$ DNA molecules). The frequency of transfection under the optimal condition was about 1 per $5 \times 10^{6} \mathrm{DNA}$ molecule (equal to $5 \times 10^{3}$ transfectants per $\mu \mathrm{g}$ DNA) and 1 per $5.3 \sim 10^{3}$ regenerated protoplasts. This result is in good accordance with those of S. lividans (Kriigel et al., 1980) and S. coelicolor (Suarez et al., 1980). Therefore, we judge that the protoplasts of S. azureus have transfection activity.

\section{Time course of phage growth in protoplasts}

The time course of phage growth in the protoplasts in R3 liquid medium after the transfection is shown in Fig. 5. The SAt 1 progenies appeared in the medium after $2 \mathrm{hr}$ incubation and the number of free phages continued to increase for the following $4 \mathrm{hr}$. This result may indicate that the latent time for growth of phage SAt 1 is $2 \mathrm{hr}$.

Transfection of the protoplasts of various Streptomyces strains with phage SAt1 or phage SAv1 DNA

The transfection system established above was adapted to other Streptomy. ces organisms and a virulent phage SAv 1. Thus, experiments were carried out to understand whether or not their protoplasts can produce phage proge- 


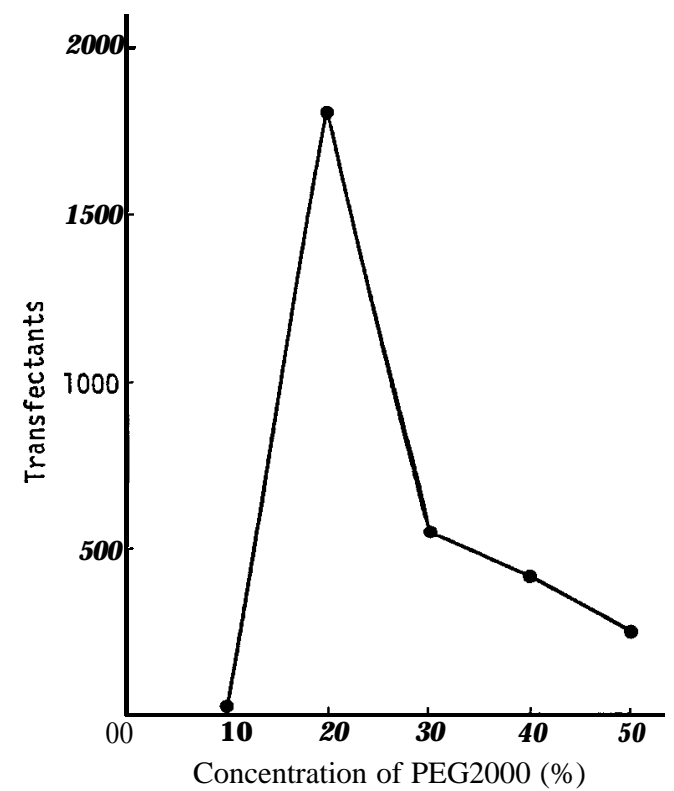

Fig. 3. Effect of PEG2000 concentration on the frequency of transfection of Streptomyces azureus protoplasts with phage SAt 1 DNA. About $8 \times 10^{6} \mathrm{cfu}$ protoplasts of S. azureus were used for each transfection experiment.

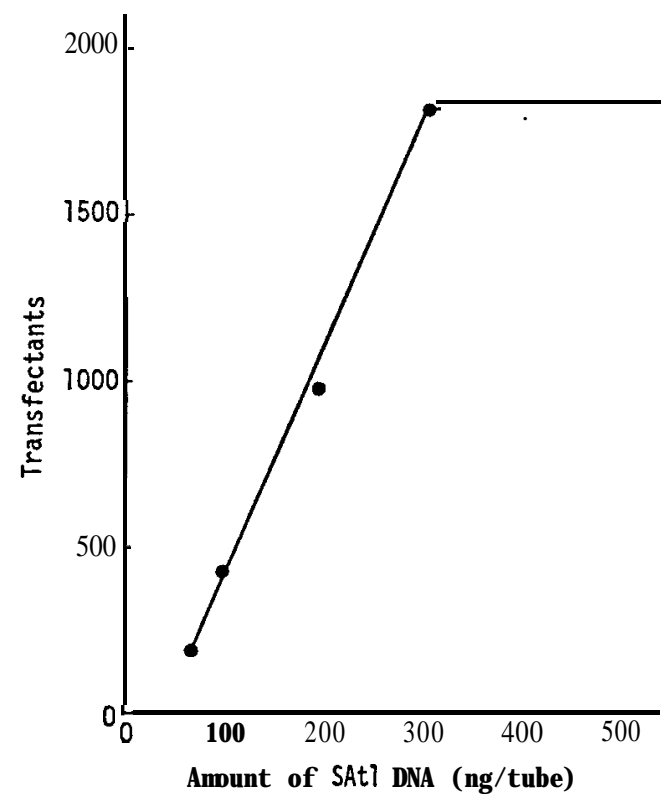

Fig. 4. Relationship between the amount of phage SAt1 DNA and transfection frequency. About $8 \times 10^{6} \mathrm{cfu}$ protoplasts of $\mathrm{S}$. azureus were used for each transfection experiment. 


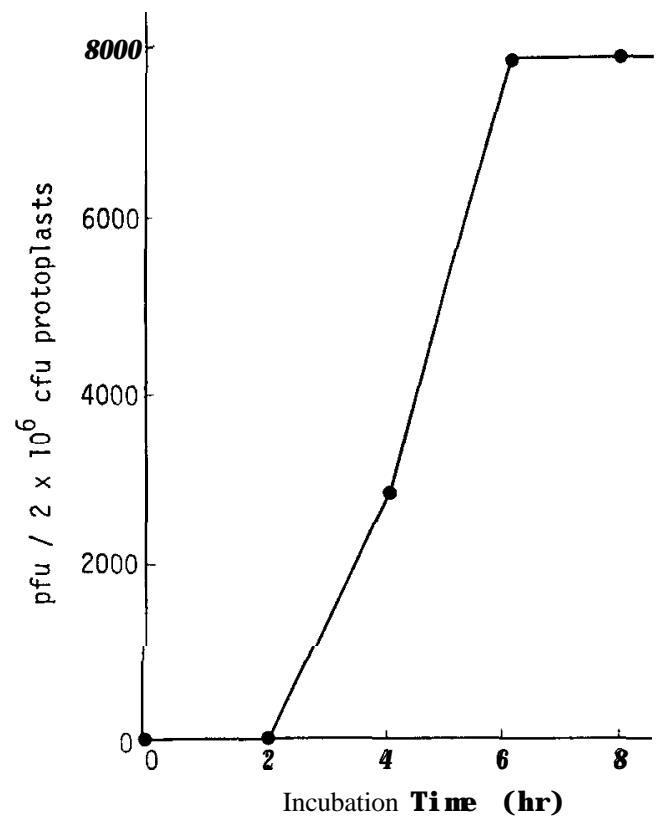

Fig. 5. Time course of development of phage SAt 1 after transfection of Streptomyces azureus protoplasts. $2 \times 10^{6}$ cfu protoplasts contained about 400 transfectants.

pfu: plaque forming units.

Table 2. Transfection of phage SAt 1 DNA and phage SAv 1 DNA on the protoplasts of various Streptomyces species.

\begin{tabular}{|c|c|c|c|c|c|}
\hline \multirow[b]{2}{*}{ Organism } & & \multicolumn{2}{|c|}{ Phage SAt 1} & \multicolumn{2}{|c|}{ Phage SAv 1} \\
\hline & & DNA & Phage & DNA & Phage \\
\hline Streptomyces azureus & ATCC 14921 & + & + & + & + \\
\hline S. viridochromogenes & NRRL B-1511 & - & - & + & + \\
\hline S. viridochromogenes & KCC S-0094 & - & - & + & + \\
\hline S. viridochromogenes & KCC S-0265 & - & - & + & + \\
\hline S. griseus & NRRL B-2926 & - & & + & + \\
\hline S. lividans & KCC S-0783 & & & + & - \\
\hline S. endus & KCC S-0213 & & & - & - \\
\hline S. rimosus & KCC S-0073 & - & - & - & - \\
\hline S. coerulescens & KCC S-0360 & - & & - & - \\
\hline S. labendulae & KCC S-0263 & - & & - & \\
\hline
\end{tabular}

+: production of phage progenies, - : no production

nies by infection of phenol-extracted phage DNA.

As shown in Table 2, phage SAt 1 had a very narrow host range and could infect only one strain, S.azureus. The DNA transfection of phage SAt1 was also limited only on the protoplasts of S. azureus. From this results, we judge that the narrow host range of phage SAt 1 is not due to the absence 
S. azureus pock ${ }^{-} \quad$ S. azureus pock+

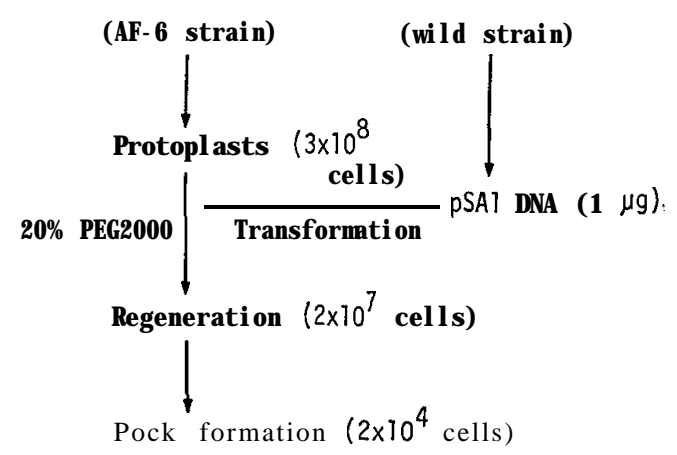

Fig. 6. Transformation of Streptomyces azureus AF-6 (pock- strain) protoplasts with pock-inducing pSA 1 plasmid DNA.

of receptors on the cell surface of various Streptomyces strains used. On the other hand, phage SAv 1 had a wide host range and could infect S.azureus, 3 strains of S. viridochromogenes and S. griseus. The DNA transfection of phage SAv 1 was occurred on the protoplasts of these organisms. Phage SAv 1 could not infect intact cells of S. lividans, but its DNA transfection was succeeded in the protoplasts of $\mathrm{S}$. lividans. This result implies that insensitivity of phage SAv 1 to intact cells of S. lividans is due to the absence of phage receptors on the cell surface of S. lividans. Therefore, in the case of DNA transfection using protoplasts, the phenol-extracted DNA penetrated into the cells could produce phage progenies.

These results indicate that the transfection system descibed here should help genetic studies of pock-forming S. azureus and other Streptomyces organisms.

\section{Transformation of protoplats with pock-inducing plasmid DNA}

As shown in in Fig. 6 the frequency of transformants representing pock formation were $10^{-3}$ of the regenerated colonies, under the same condition as transfection of phage DNA. Almost all colonies which were transformed continued to harbor pock-forming activity even after several subculturings. This result indicates that the transformation system described here should be very helpful for the genetic studies of pock-forming S. azureus and other Streptomyces organisms.

\section{REFERENCES}

Bibb, M. J., J. M. Ward and D. A. Hopwood 1978 Transformation of plasmid DNA into Streptomyces at high frequency. Nature, 274: 398-400

Chater, K. F., D. A. Hopwood, T. Kieser and C. J. Thompson 1982 Gene cloning in Streptomyces. Curr. Top. Microbiol. Immunol., 96: 69-95

Higashi, N. 1973 Preparation of samples for electron microscopy. In "Electron microsco- 
py practices for biology and medicine," ed. by N. Higashi and S. Tohyama, Kyoritsu Shuppan, Tokyo, pp 99-145

Isogai, T., H. Takahashi and H. Saito 1980 High-frequency protoplast-transfection of Streptomyces parvulus 2297 with actinophage R 4 DNA. Agric. Biol. Chem., 44: 2425-2428

Krügel, H., G. Fiedler, and D. Noack 1980 Transfection of protoplasts from Streptomyces lividans 66 with actinophage SH 10 DNA. Mol. gen. Genet., 177 : 297-300

Maniatis, T. 1982 Large-scale isolation of plasmid DNA. In "Molecular cloning," ed. by Maniatis, T., E. F. Fritsh and T. Sambrook, Cold Spring Harbor Laboratory, New York, pp 88-96

Ggata, S., S. Yoshino, H. Suenaga, K. Aoyama, N. Kitajima and S. Hayashida 1931 Specific lysogenicity in Sreptomyces azureus. Appl. Environ. Microbiol., 42: 135-141

Ogata, S., Y. K-Miyoshi, Y. Sakaki and S. Hayashida 1983 Isolation of linear DNA associated with pock formation in Streptomyces azureus. Agric. Biol. Chem., 47: 2127-2129

Ogata, S., H. Suenaga and S. Hayashida 1985 A temperate phage of Streptomyces azureus. Appl. Environ. Microbiol., 49: 201-204, 1985

Ogawa, H., S. Imai, A. Satoh and M. Kojima 1983 An improved method for the preparation of Micromonospora and Streptomycetes protoplasts. J. Antibiot., 36: 184-186

Okanishi, M., K. Suzuki and H. Umezawa 1974 Formation and reversion of Streptomycete protoplasts: Cultural condition and morphological study. J. Gen. Microbiol, 80: 349400

Pigac, J., D. Hranueli, T. Smokvina and M. Alacevic 1982 Optimal cultural and physiological conditions for handling Streptomyces rimosus protoplasts. Appl. Environ, Microbiol., 44: 1178-1186

Shirahama, T., T. Furumai and M. Okanishi 1981 A modified regeneration method for Streptomycete protoplasts. Agric. Biol. Chem., 45 : 1271-1273

Suarez, J. E. and K. F. Chater 1980 Polyethylene glycol assisted transfection of Streptomyces protoplasts. J.Bacteriol., 142: 8-14

Thompson, C. J., J. M. Ward and D. A. Hopwood 1980 DNA cloning in Streptomyces: resistance genes from antibiotic-producing species. Nature, 286: 535-527

Toyama, H., E. Hayashi, K. Nagaoka and Y. Yamada 1983 Protoplast-transfection of Streptomyces chartreusis SF 1623 with actinophge or 5 DNA. Agric. Biol. Chem., 47: 18591864 